Capel, S. and Blair, R. (2007) Moving beyond physical education subject knowledge to develop knowledgeable teachers of the subject, Curriculum Journal, 18 (4), 493-507.

\title{
Moving beyond physical education subject knowledge to develop knowledgeable teachers of the subject
}

\author{
Susan Capel, Brunel University
}

\begin{abstract}
All knowledge is socially constructed, including physical education teachers' knowledge of their subject. It is acquired from other people either formally and deliberately (e.g. by being taught) or informally and casually (e.g. by interacting with physical education teachers or playing in a sports team). The social aspects of learning appear to be particularly strong in physical education. This has implications for the development of knowledge for teaching, with trainee teachers focusing on the development of subject, and particularly content, knowledge. Focusing on subject knowledge reinforces a traditional view of physical education as it is, not as it might be to meet the needs of young people today. It is argued that attention needs to be given not only to the knowledge, skills and competencies that trainee teachers ought to develop but also to the social aspects of their learning and development and the context in which they learn. Attention also needs to be given to how the ability to think critically can be developed so that trainee teachers can become reflective practitioners able to challenge and, where appropriate, change the teaching of the subject. Only by doing this can the particularly strong socialisation which shapes the values and beliefs of physical education teachers begin to be challenged. However, as the process of developing knowledgeable teachers is ongoing it is also necessary to look beyond teacher training to continuing professional development.
\end{abstract}

Key words: knowledgeable teachers; physical education; subject knowledge

\section{Introduction}

The teaching of physical education in many schools is based on a sporting model. This model focuses largely on the acquisition and performance of skills in a multi-activity curriculum organised mostly around team games, taught with a limited range of teaching approaches most of which are formal, didactic and teacher-centred (see, for example, Curtner-Smith, 1999; Fairclough and Stratton, 1997; Green, 1998; Kirk and Kinchin, 2003; Mawer, 1999; Metzler, 2000; Ofsted, 1995, 2002; Penney and Evans, 1994 \& 1999). Evans (1992, p.239) describes what he calls the 'sporting perspective' as:

subject centred, concerned with the development of physical skills and maintaining standards within a meritocratic system, and with fostering enjoyment and a love of sport amongst all children while securing the potential of elite performers and the more physically able child.

Thus, the traditions of sport are perpetuated through a traditional physical education curriculum. As a result, the physical education taught in schools does not prepare young 
people for participation in many types of sport, exercise and physical activity experienced outside school. One result of this is that many young people are alienated from physical education and therefore physical activity (see Kirk and Macdonald, 1998). Indeed, Kirk and Macdonald (1998, p.381) argue that 'the form of learning represented in school may have little transfer value to related situations outside school. This is problematic if the aim of school physical education is to prepare pupils to pursue an active lifestyle in adulthood'. Low participation in a physically active, healthy lifestyle after leaving school is worrying, particularly at a time when the incidence of obesity is rising.

Although pupils and others may perceive other subjects taught in schools to have little transfer value to related situations outside school, this may not be seen as problematic. This may be partly because of the perception of the importance and value of educating the mind in our schools, and conversely, the low importance and value of the body, and hence physical education, to pupils' education. One outcome of this is that, for some at least, physical education is equated to recreation or 'a break from classroom work'; thus, its contribution to the 'informal curriculum' is thought to be almost as important as its place in the formal curriculum (see, for example, Evans and Davies, 1986). This may contribute to the relatively low, marginal status of physical education in the hierarchy of subjects in the education system. This has resulted in an ongoing concern for physical educationists in schools and higher education to justify the place of the subject in the curriculum. On the other hand, the contribution of other subjects may be self-evident; justifying their place in the curriculum. Although one (and arguably perhaps the most important) justification for the subject in the curriculum is its unique contribution to the development of motor skills (particularly gross motor skills), there have been, and continue to be, different extrinsic justifications for the subject in schools, including sports performance, health, and personal and social development (see, for example, Fitzclarence and Tinning, 1990). Recently, the government has identified an important role for physical education in raising pupils' attainment and as a tool for whole-school improvement (see, for example, Teachernet, 2007).

These different justifications suggest that there is little agreement about what the subject is. Further, different justifications might suggest that different aims and objectives, curriculum content and teaching approaches should be adopted. As a result, it might be expected that physical education programmes in our schools should be very different. However, physical education in the majority of schools looks very similar. There seems to be an implicit agreement as to what should be included in the curriculum and how it should be taught, with the focus being largely on the sporting model. Reasons for this are complex. The socialisation of a culturally specific professional community which has a particularly strong identity is considered next, followed by the impact of this socialisation on trainee teachers' development as teachers.

\section{Socialisation}

All knowledge is socially constructed, including physical education teachers' knowledge of their subject. It is acquired from other people either formally and deliberately (e.g. by being taught) or informally and casually (e.g. by interacting with other people). The social aspects of learning in physical education appear to be particularly strong and they have an impact on what knowledge trainee teachers (and their mentors) identify is important to develop and therefore what knowledge trainee teachers actually develop. Perceptions, values, beliefs, attitudes, behaviours and practices about content, teaching and teaching philosophies are 
influenced. This strong socialisation is one of the major reasons why a sporting model is perpetuated in physical education.

The strength of socialisation into teaching physical education has been recognised over a long period of time. Research, much of which is based on that conducted initially by Lortie (1975) and then Lawson (1983a \& b), has identified a number of socialising factors which shape physical education teachers' knowledge and beliefs about the purpose of physical education, its content and teaching approaches. These include childhood and adolescent experiences. Experiences in physical education, sport (both in and out of school), success in education and in sport and interactions with physical education teachers, coaches and others working in physical activity and sport contexts with whom the prospective teacher comes into contact, are all influential (see, for example, Curtner-Smith, 1999; Dewar and Lawson, 1984; Dodds et al., 1992; Evans and Williams, 1989; Evans et al., 1995; Green, 1998; Mawer, 1996; Schempp, 1989; Templin, 1979). However, research has shown that many physical education teachers are motivated to enter the profession because of their experiences, and success, in sport as opposed to physical education (e.g. Stidder and Hayes, 2006).

Research suggests that new entrants to the profession (and teachers) with good knowledge of an activity through participating at a high level are more likely to hold a conservative orientation towards physical education, reinforcing a traditional curriculum, content and teaching approaches (e.g. Lawson, 1986). On the other hand, those with a broader knowledge through participation in a range of non-traditional sports and other types of physical activity at a recreational level are more likely to hold an innovative orientation towards the subject.

The conservative approach is exacerbated by many new entrants to physical education having experienced a limited physical education curriculum at school, comprising mostly games and sports activities taught in a traditional way. However, there is considerable flexibility embedded in the National Curriculum for Physical Education (DfEE/QCA, 1999) including a range of aims, designed to justify the subject in a number of ways to satisfy a range of interests and beliefs. These include sports performance, health and personal and social development. The requirements for teaching content both favour traditional team games and mean that some areas of activity need never be taught in schools. This may be underpinned by both implicit and explicit messages from school management, government and others about the importance of team games and school teams and identifying talented performers. As a result, Evans and Penny (1992) and Penney and Evans (1997) have found that many teachers in England adapt, modify and recreate the National Curriculum for Physical Education to match their existing beliefs. This allows teachers to continue to teach what they have always taught and how they have always taught it and allows new entrants to the profession to teach what and how they were taught which, for many, is what they value and believe. A further exacerbating factor is that many entrants to physical education teaching follow a one year post-graduate certificate in education programme, having undertaken a sport sciences degree course. Because the theoretical nature of sport sciences degrees does not prepare students for the practical nature of physical education as taught in schools, trainee teachers rely on knowledge gained from experience outside their degree course for teaching the curriculum. The strong socialisation and motivation to teach based on sporting performance, plus their limited experiences in physical education in school and input through their first degree, results in many entrants to physical education valuing a traditional curriculum, content and teaching approach. Together, these may mean that 
trainee teachers find it hard to understand that there can be alternative approaches to curriculum, content and teaching which can be used.

In teacher training, trainee teachers learn the official requirements (e.g. subject knowledge and technical competence) through formal means (e.g. lectures, assessments in universityand school-based parts of the programme). However, they also learn what it means to be part of the profession by acquiring shared perceptions, values, beliefs, attitudes, behaviours and practices (Gabbe, Bury and Elston, 2004) through informal means (e.g. interacting with physical education teachers). It is likely that the curriculum in most schools in which the majority of trainee teachers are placed on school experience is dominated by games and sports activities. Many are mentored by physical education teachers who, as Curtner-Smith (2001, p.83) suggests, 'wanted to coach school sports teams', but became teachers because it gave them a secure job with a stable income and, as Tsangaridou (2006, p. 492) suggests, appear to view 'teaching as a career contingency for coaching'. As a result, the previous experiences, perceptions, values and beliefs of many trainee teachers are reinforced. Indeed, research suggests that beliefs about physical education developed prior to teacher training are not easily changed and that teacher training has relatively little impact on trainee teachers (Curtner-Smith, 1999; Evans, 1992; Evans et al., 1996; Green, 1998; Placek et al., 1995). Research has also found that teacher training does not tend to challenge trainee teachers' values and beliefs about physical education and in teacher training many trainee teachers confirm, rather than modify, their values and beliefs (Doolittle et al., 1993; Solmon and Ashy, 1995).

Once qualified, teachers learn the values, beliefs, attitudes, behaviours and practices required in the role of a teacher whilst on the job. Practice can be developed or restricted, particularly early on in a teacher's career, by the context in which they are working (Capel, 2005; Lawson, 1983a \& b). When they enter their first (and subsequent) jobs newly qualified (and more experienced) teachers usually join teachers already in post who generally want continuity and to carry on as they are. The majority of these teachers coach teams outside their work as teachers. Some of their coaching experiences, and the knowledge they have gained from various coaching courses they have taken, form a large part of their craft knowledge. Indeed, an integral part of continuing professional development for many teachers is a scheme called 'Coaching for Teachers'. Thus, they focus on improving sports performance in both physical education lessons and in extracurricular activities.

According to Stroot and Ko (2006, p.427) a newly qualified teacher 'learns, accepts and implements ... the customary strategies' and, according to Tsangaridou (2006), rarely questions the ways things are. However, there may be different reasons for this acceptance and lack of questioning. If the values and beliefs of the incoming teacher are similar to those of the teachers already in post, these are likely to be reinforced and strengthened; hence, they are unlikely to have to change their behaviours and practices. On the other hand, if the values and beliefs of the incoming teacher are different to those of the teachers already in post, they are likely to have to adapt their behaviours and practices, and maybe also their values and beliefs, in order to fit in. Fitting in - the informal learning, is likely to be a stronger influence than the formal learning from their teacher training programme. As a result, many teachers who might want to be innovative and introduce different or new practices to which they were introduced in teacher training do not feel able to do so (see, for example, Stroot and Ko, 2006). Thus, the impact of formal learning in teacher training is negated relatively soon after newly qualified teachers start in their first post. This strong 
socialisation in school is reinforced because many physical education teachers socialise with people who are also interested/participate in sport and physical activity and, hence, hold similar interests, attitudes, values and beliefs. Thus, the status quo is reinforced.

Thus, childhood and adolescent experiences in sport and physical education, experiences through which trainee teachers are initiated into teaching physical education, learning on the job once qualified as a teacher, and social experiences outside work, are all factors in the strong socialisation of physical education teachers. Throughout this socialisation, sporting experiences are dominant and therefore most influential. One result of this strong socialisation is that many physical education teachers do not differentiate between their physical education and sporting experiences, therefore equate physical education with sport. This is reinforced by messages received from others. As a result, they prioritise sport and perpetuate a sporting model in teaching physical education. The next section explores the implications of this strong socialisation on developing knowledge for teaching.

\section{Implications for developing knowledge for teaching}

One characteristic of a profession is its recognised body of knowledge. However, the knowledge that distinguishes teachers as professionals is contested and problematic (see, for example, Hoyle and John, 1995). There are a number of theoretical models which conceptualise knowledge for teaching. Bain (1990) identified socialisation as one of three paradigms for research into knowledge for teaching physical education: the other two being behaviourist and critical theory. Munby et al. (2001) classified models into theoretical or propositional and practice-orientated. They also recognised a 'gradual reconciliation [of the two] reinforces our view of the complexity involved in rendering the field into neat and exclusive categories' (p.878). Banks, Leach and Moon (1999) give three perspectives: the curriculum perspective, the learner perspective and the pedagogical perspective. The most commonly used model of the conceptualisation of knowledge for teaching in physical education is that of Shulman $(1986 ; 1987)$ who takes a curriculum perspective. Much of the research in physical education has focused on two of Shulman's seven knowledge bases: content knowledge and pedagogical content knowledge (see, for example, Amade-Escot, 2000).

Although the knowledge that distinguishes teachers as professionals is contested and the concept of knowledge for teaching is problematic, this does not seem to be true in physical education. Rather, research suggests that the knowledge identified as being important for teaching the subject is not generally contested, at least by those practising in our schools. Research suggests that trainee physical education teachers and their mentors generally have a limited view of the knowledge needed for teaching and this knowledge reinforces the traditional approach to teaching the subject (see, for example, Capel and Katene, 2000; Capel, et al., 2007; Gower and Capel, 2004; Hayes, et al., 2007). Although some trainee teachers identify pedagogical content knowledge as important, the knowledge identified by the majority focuses largely on the knowledge required to teach the six areas of activity of the National Curriculum for Physical Education and theoretical aspects of examinations to pupils between 14 and 18 years, i.e. content knowledge. Further, within content knowledge, the development of knowledge for the immediate practical situation, i.e. knowledge in areas of activity/activities in which trainee teachers have limited knowledge and which they are going to be teaching on school placement, is prioritised. It is understandable why trainee teachers do not prioritise further development of knowledge in areas of activity/activities in which they identify themselves as good on entry to a teacher training programme. As a result, they rely on their existing knowledge and teaching approaches from their own, often 
sporting, background to teach an activity. Thus, they do not explore different ways of teaching the content through developing their pedagogical content knowledge from their teacher training programme. Research therefore shows that trainee physical education teachers are likely to teach this content the way they were taught themselves. In relation to games, they are likely to teach the content in the way they were coached themselves.

The prioritisation of knowledge for the immediate teaching situation on school placement may be explained, at least in part, by a third theoretical framework; phases of development. For example, Fuller's (1969) 'Phases of Concern' model identifies three concerns through which trainee teachers progress as they learn to teach: self concerns (concern about themselves and their teaching technique; survival); task concerns (concern about delivery of content or material, irrespective of the pupils response); and impact concerns (concern for the pupils and the process of learning) (see also Fuller and Brown, 1975). Other authors (e.g. Maynard and Furlong, 1993) offer slightly different categorisations. However, the underlying premise of these categorisations is very similar in relation to progression through phases of development or concerns focusing on self, content and then pupils, as trainee teachers develop their own skills and competence.

Thus, early in their school placements, trainee teachers are likely to be concerned about 'getting through' and surviving. When standing in front of a group of pupils, trainee teachers are likely to be concerned about being able to respond appropriately to questions pupils might ask. Such questions are likely to revolve around the skills, rules or tactics of the activities in which the pupils are participating. Hence, they are concerned about accumulating school-based practical experience of teaching to help them learn to cope with the day-to-day realities of teaching and with having enough content knowledge for the lesson (Tinning, 2006).

Results of some research on the concerns of trainee physical education teachers support a sequential model of development (e.g. Boggess et al., 1985, Fung, 1993, Hardy, 1995 \& 1997; Meek, 1996; Wendt and Bain, 1989), although they do not all progress through the various concerns at the same rate and therefore different trainee teachers may be at different phases of development at different times during their teacher training. On the other hand, Capel (1997) suggests that development is not sequential. She found that the causes and intensity of concern remain the same over the course of a teacher training programme. She suggests that the new environment of each school placement results in trainee teachers refocusing first on self concerns and then on content. Whether development is sequential or not, results of research suggest that trainee teachers focus on the immediate practical concerns of self and content and most are not able or ready in teacher training to prioritise the development of knowledge to enable them to meet the needs of individual pupils.

This may be exacerbated by the nature of teacher training in England in which a large proportion of time is 'devoted to enabling teachers to "deliver" the curriculum' (Hallam and Ireson, 1999, p. 83), which is assessed on the basis of achieving specific, mainly observable, outcomes. This is reinforced by many mentors who see their role as a practical one of passing onto trainee teachers advice about the day-to-day demands of teaching physical education, focused upon 'the immediate, practical issues of subject-specific teaching and classroom management and control' (Booth, 1993, p.194). They do this by focusing on three main aspects of physical education: managing and delivering lessons, lesson content, and reflecting on their teaching of the lesson. 
Research also shows that mentors generally have a greater impact than university tutors on trainee teachers' development of knowledge (see, for example, Capel et al., 2007). This reinforces the perception that the practice, or doing, of teaching is more important than theorising, and school placements are more important than university-based work in developing trainee teachers' knowledge for teaching. Thus, if what they practice or do in physical education lessons in schools and what they are taught in teacher training are different or conflicting, trainee teachers are likely to accept, or prioritise, the school-based and dismiss the university-based parts of the programme as not relevant to their work in schools. They may therefore believe that the theory or alternative practices (such as pedagogy, teaching approaches or curriculum models) they are taught in the universitybased part of the programme is necessary to qualify as a teacher, but is not relevant to them on school placement or later as a teacher. This is why mentors (and other teachers in school) have a more important role in the socialisation of trainee teachers and therefore upon their values and beliefs, attitudes and teaching behaviours than their university tutors (see, for example, Behets and Vergauwen, 2006).

In terms of knowledge for teaching, one result of this is that, as presently conceptualised, physical education teacher training does not seem to enable trainee teachers to integrate different bodies of knowledge for teaching. Another is that many trainee physical education teachers and their mentors perceive there to be a contained, static, fixed and external body of (content) knowledge for teaching the subject. Thus, many physical education teachers and trainee teachers see content and teaching approaches as 'self-evident' and 'unproblematic' (Thomson, 1999), resulting in what Penney and Evans (2005, p. 21) called 'the taken-for-granted routines in physical education'. Values and beliefs, behaviour and practice are not challenged and the teacher uses established routines and practices that they do not want disrupted.

Rossi and Cassidy (1999, p. 189) highlight that 'whilst this [technical] learning is important, it is sometimes elevated to a significance perhaps out of proportion with its functional utility and reduces the teacher to little more than a technician', with teaching being regarded as a low-grade activity undertaken by trained technicians having served their apprenticeship. Thus, for example, trainee teachers know what teaching approach to use to achieve a particular learning outcome, but may not be able to articulate why that outcome is important. The focus is therefore on a process-product 'if do this, then that happens' model, rather than a model which focuses on why and in which the complex, problematic nature of teaching and learning and of physical education is promoted. The traditional approach to teaching the subject is likely to be reinforced because trainee teachers generally deliver the curriculum without questioning how or why an activity is being taught and its impact on pupils. Thus, there is a self-perpetuating cycle and prior socialisation is reinforced.

Stidder and Hayes (2006) suggest that although this may better prepare trainee teachers to teach specific activities in a specific school, it does not help to prepare them as teachers of children and not of the subject. Flintoff and Scraton (2006, p. 774) argue that physical education teacher training "prepare[s] students to teach in schools "as they are", rather than as they might be'. If physical education is going to meet the needs of young people today, it is argued that we need physical education teachers who are more than technicians who replicate their own experiences or copy those of the mentor. We need physical education teachers who can challenge and, where appropriate, change the teaching of the subject. It is 
argued that attention needs to be given not only to the knowledge, skills and competencies that trainee teachers ought to develop but also to the social aspects of their learning and development and the context in which they learn, as this impacts on the knowledge that trainee teachers (and their mentors) identify as being important to develop and therefore what knowledge trainee teachers actually develop. Attention also needs to be given to how the ability to think critically can be developed so that trainee teachers develop into reflective practitioners able to challenge and, where appropriate, change the teaching of the subject. Only by doing this can the particularly strong socialisation which shapes the values and beliefs of physical education teachers begin to be challenged and 'knowledgeable teachers' (Rossi and Cassidy, 1999) developed.

\section{Developing knowledgeable teachers}

What are knowledgeable teachers? Although this may be contested, a starting point could be that knowledgeable physical education teachers should take a pupil- rather than subjectcentred approach, and place pupils' learning at the heart of their teaching. They should be clear about why physical education is taught in schools, the aims and purposes of the subject and are able to plan their content and teaching approaches to enable them to work towards achieving those aims. They should pay as much attention to why they are teaching specific content as to how they are teaching it. To achieve this, Rossi and Cassidy (1999) argue that trainee teachers need to be able to reflect on all aspects of physical education so that they can critically evaluate the conventions and routines they have absorbed during their own university-based education, and while on school placement during their teacher training programme, to inform their own practice. This enables them to challenge their own and others beliefs and practices, the curriculum content they teach and the teaching approaches they adopt. Thus, knowledgeable teachers not only have the relevant knowledge and technical expertise to teach a limited range of activities in a particular way or in a particular school, they also know why they plan the what and how they are going to teach, so that the curriculum is relevant to the pupils they are teaching. It is argued that if the focus of teacher training is on developing knowledgeable teachers; rather than on developing the knowledge to teach, there is a greater likelihood of trainee teachers being better prepared to challenge the status quo.

However, in order to achieve this, it is argued that attention needs to be given to developing cognitive skills which underpin reflection, to enable trainee (and qualified) physical education teachers to consider teaching and learning in physical education in a problematic way.

Evidence suggests that students enter undergraduate education with a surface approach to learning, motivated by the desire to meet minimum requirements with minimum effort and that this is maintained throughout their programme (e.g. Entwistle and Tait, 1990; Gow and Kember, 1990; Lawrence et al., 2006; Marton and Saljo, 1997) and teacher training (Marton et al., 1993; Vermunt, 1996). These trainee teachers are likely to focus on memorising and reproducing material without analysing or integrating it and to model the teaching approaches of their own teachers and those they observe in schools. Reflection is likely to be limited to the specific lesson or unit of work. Therefore, rather than challenging or changing values and beliefs, prior socialisation is likely to be reinforced. On the other hand, trainee teachers with a deep approach to learning are motivated by a desire to understand the material and therefore use complex reasoning to reflect on, analyse and challenge a variety of views on the problematic nature of teaching and learning in physical 
education. They are, therefore, able to challenge their own and others values, beliefs and attitudes, which provides a platform for changing their own behaviours and practices. Williams (1993) identified three broad forms of reflective practice. That used most frequently is the weakest form of reflection. This instrumental form of reflection or 'utilitarian mechanism for improving the execution of teaching skills' (Williams, 1993, p. 137) helps trainee teachers to replicate practices that have been found to be effective, either through their own experience or through research that has taken a technical perspective. The second form of reflection is 'a form of deliberation among competing views of teaching'. Thus, for example, 'a teacher who is able to use a variety of [teaching] styles is more likely to be able to select the most effective for a specific learning activity' (Williams, 1993, p. 139). This form of reflection is underpinned by research which is used to inform rather than direct practice. The third, and strongest, form of reflection is 'the reconstruction of oneself as a teacher, with an expectation that teachers will become more aware of the cultural milieu in which they operate' (Williams, 1993, p. 140). This involves teachers reviewing and reconstructing the taken for granted assumptions about physical education, about teaching physical education and about education. This form of reflection draws on research that views teaching and learning in physical education as problematic. Although trainee teachers may engage in the weakest form of reflection early on in learning to teach, the aim is for the strongest form of reflection to be used to inform teaching. However, the strongest form of reflection will only occur if trainee teachers have a desire to understand the material and engage in complex reasoning.

If one of the stated goals of many physical education teacher training programmes to develop reflective practitioners is to be achieved, the development of a deep approach to learning and reflection needs to be actively promoted (Gordon and Debus, 2002). Although both school- and university-based staff have a key role in maximising or hindering trainee teachers' ability to reflect, particular attention should be given to the role of school-based mentors. It is unlikely that the strong form of reflection can be achieved if the focus is on developing practical skills and competencies and if mentors generally encourage trainee teachers to reflect on the day-to-day teaching of lessons and rarely encourage them to reflect more broadly on the subject or teaching, or challenge their own and others values and beliefs. Further, the role of mentors in the assessment of trainee teachers makes them particularly influential and powerful. One outcome of this is that many trainee teachers accept the established views of their mentors and, if their own preferred content and teaching approaches differs from that of their mentor, copy their mentor, teaching what and how their mentor or other teachers teach (Capel, et al., 2007; Mawer, 1996). Thus, the attitudes of all staff, but particularly mentors, and their openness to new practice, are important in either supporting trainee teachers in developing into reflective practitioners or becoming competent technicians. Further, the methods of assessment must also enable reflection to be rewarded. If priority, and therefore attention, is given to trainee teachers providing evidence of meeting a number of identified competencies/ standards, then it is that knowledge that is likely to be prioritised and it is unlikely that reflective abilities will be developed.

It is argued that, in supporting the development of knowledgeable teachers, it is not enough just to concentrate on the cognitive processes and skills required to reflect and the content of reflection. Attention also needs to be given to the socialisation in their learning and development and the context in which they learn. 


\section{Conclusion}

Research shows that, in learning to teach, trainee physical education teachers and their mentors prioritise the development of subject knowledge (many focusing more narrowly on content knowledge and particularly knowledge of activities in which they have little prior knowledge and which they are going to be teaching on school placement). Trainee teachers teach much content on school placement in the way they have been taught or the way their mentor teaches it. Thus, the focus of their teacher training is on developing content knowledge and technical expertise to teach a specific activity in a specific school. However, it is argued that it is not enough to have competent technicians with good content knowledge in some areas of activity/activities in the National Curriculum for Physical Education. Whilst knowledge for teaching, including subject knowledge, is important for teaching physical education, attention needs to be given to a range of interacting factors to take account of the complex nature of teaching and learning, if physical education is to justify its place in the school curriculum. This is difficult to capture in existing models of knowledge for teaching.

It is argued that as well as paying attention to the knowledge, skills and competencies that trainee teachers ought to develop, attention also needs to be given to the social aspects of their learning and development and the context in which they are learning. These impact on what knowledge trainee teachers (and their mentors) identify as important to develop and therefore what knowledge trainee teachers actually develop. Attention also needs to be given to the ability to think critically so that trainee teachers develop into reflective practitioners able to challenge and, where appropriate, change the teaching of the subject. This may enable the particularly strong socialisation which shapes the values and beliefs of physical education teachers to be challenged and knowledgeable teachers developed. In teacher training, the focus is on achieving a set of standards/competencies to qualify as a teacher, and trainee teachers being concerned about being comfortable with the role of the teacher and then with the content of the subject, it may only be once they have qualified as teachers that they are able to focus on the needs of individual pupils and on their own wider development and can begin to question and challenge. However, the constraints of physical education teaching mean that there are seldom opportunities for teachers to analyze and reflect upon their teaching. It is important that such opportunities are provided through continuing professional development, and that this should be done early in a teacher's career before they become established and generally more conservative.

\section{References}

Amade-Escot, C. (2000) The contribution of two research programs on teaching content: 'pedagogical content knowledge' and 'didactics of physical education', Journal of Teaching in Physical Education, 20, 78--101.

Bain, L. (1990) Research in sport pedagogy: past, present and future, in sport and physical activity: moving towards excellence, in: Proceedings of the AIESEP World Convention, Loughborough University, July.

Banks, F., Leach, J. and Moon, B. (1999) New Understandings of Teachers' Pedagogic Knowledge. In J. Leach and B. Moon (eds.) Learners and Pedagogy, 89-110. (London, Paul Chapman Publishing in association with The Open University).

Behets, D. and Vergauwen, L. (2006) Learning to teach in the field, in: D. Kirk, D. Macdonald and M. O'Sullivan (Eds) The handbook of physical education (London, Sage), 407--424. 
Boggess, T., McBride, R. and Griffey, D. (1985) The concerns of physical education student teachers: a developmental view, Journal of Teaching in Physical Education, 4, 202--211.

Booth, M. (1993) The effectiveness and role of the mentor in school: the students' view, Cambridge Journal of Education, 23 (2), 185--197.

Capel, S. (1997) Reflections on school experiences by PE students learning to teach in secondary school in England and Wales, paper presented at the International Association for Physical Education in Higher Education Conference, Singapore, December.

Capel, S. (2005) Teachers, teaching and pedagogy in physical education, in: K. Green and K. Hardman (Eds) Physical education: essential issues (London, Sage Publications), 111--127.

Capel, S. and Katene, W. (2000) Secondary PGCE PE students' perceptions of their subject knowledge, European Physical Education Review, 6 (1), 46--70.

Capel, S., Hayes, S., Katene, W. and Velija, P. (2007) Secondary student physical education teachers development of knowledge for teaching over the course of a PGCE year, manuscript under review.

Curtner-Smith, M.D. (1999) The more things change the more they stay the same: factors influencing teachers' interpretations and delivery of National Curriculum Physical Education, Sport, Education and Society, 4 (1), 75--97.

Curtner-Smith, M. (2001) The occupational socialization of a first-year physical education teacher with a teaching orientation, Sport, Education and Society, 6 (1), 81--105.

DfEE/QCA (Department for Education and Employment and Qualifications and Curriculum Authority) (1999) Physical education: The National Curriculum for England (London, HMSO) (also available at: www.nc.uk.net)

Dewar, A. and Lawson, H. (1984) The subjective warrant and recruitment into physical education, Quest, 36, 15--25.

Dodds, P., Placek, J.H., Doolittle, S., Pinkham, K.M., Ratliffe, T.A. and Portman, P.A. (1992) Teacher/coach recruits: background profiles, occupational decision factors, and comparisons with recruits into other physical education occupations, Journal of Teaching in Physical Education, 11, 161--176.

Doolittle, S.A., Dodds, P. and Placek, J.H. (1993) Persistence of beliefs about teaching during formal training of preservice teachers, Journal of Teaching in Physical Education, 12, 355--365.

Entwistle, N. and Tait, H. (1990) Approaches to learning, evaluations of teaching, and preferences for contrasting academic environments, Higher Education, 19, 169--194.

Evans, J. (1992) A short paper about people, power and educational reform. Authority and representation in ethnographic research subjectivity, ideology and educational reform: the case for physical education, in: A. Sparkes (Ed.) Research in physical education and sport: exploring alternative visions (London, Falmer Press), 231--247.

Evans, J. and Davies, B. (1986) Sociology, schooling and physical education, in: J. Evans (Ed.) Physical education, sport and schooling. Studies in the sociology of physical education (London, The Falmer Press), 11--37.

Evans, J. and Penny, D. (1992) Investigating ERA: qualitative methods and policy oriented research, British Journal of Physical Education Research Supplement, 13, 2--5.

Evans, J. and Williams, T. (1989) Moving up and getting out: the classed and gendered opportunities of physical education teachers, in: T. Templin and P. G. Schempp (Eds) Socialization into physical education: learning to teach (Indianapolis, IN, Benchmark Press), 235--251. 
Evans, J., Davies, B. and Penney, D. (1995) Pedagogy, identity and difference in physical education, paper presented at the European Educational Research Association Annual Conference, Bath, September.

Evans, J., Davies, B. and Penney, D. (1996) Teachers, teaching and the social construction of gender relations, Sport, Education and Society, 1 (2), 165--183.

Fairclough, S. and Stratton, G. (1997) PE curriculum and extra curriculum time in schools in the NW of England, British Journal of Physical Education, 28 (3), 21--24.

Fitzclarence, L. and Tinning, R. (1990) Challenging hegemonic physical education: contextualizing physical education as an examinable subject, in: D. Kirk and R. Tinning (Eds) Physical education, curriculum and culture: critical issues in the contemporary crisis (London, Falmer Press), 169-192.

Flintoff, A. and Scraton, S. (2001) Stepping into active leisure? Young women's perceptions of active lifestyles and their experiences of school physical education, Sport, Education and Society, 6 (1), 5--21.

Fuller, F.F. (1969) Concerns of teachers: a developmental conceptualisation, American Educational Research Journal, 6 (2), 207--226.

Fuller, F.F. and Brown, O.H. (1975) Becoming a teacher, in: K.J. Ryan (Ed.) Teacher education. NSSE $74^{\text {th }}$ Yearbook, Part 2 (Chicago, University of Chicago Press).

Fung, L. (1993) Concerns among pre- and in-service physical educators, Physical Education Review, 16 (1), 27--30.

Gabbe, J., Bury, M. and Elston, M. A. (2004) Key concepts in medical sociology (London, Sage).

Gordon, C. and Debus, R. (2002) Developing deep learning approaches and personal teaching efficacy within a preservice teacher education context, British Journal of Educational Psychology, 72 (4), 483--511.

Gow, L. and Kember, D. (1990) Does higher education promote independent learning? Higher Education, 19 (3), 307--322.

Gower, C. and Capel, S. (2004) Newly qualified physical education teachers' experiences of developing subject knowledge prior to, during and after a Postgraduate Certificate in Education course, Physical Education and Sport Pedagogy, 9 (2), 1--19.

Green, K. (1998) Philosophies, ideologies and the practice of physical education, Sport, Education and Society, 3, 125--143.

Hallam, S. and Ireson, J. (1999) Pedagogy in the secondary school, in: P. Mortimer (Ed.) Understanding Pedagogy and its impact on learning (London, Sage), 68--97.

Hardy, C. (1995) Types of teaching problems experienced by pre-service teachers during their predominantly school-based teaching year, British Journal of Physical Education, Winter, 21--24.

Hardy, C. (1997) Sources of conflict during the school experience of pre-service physical education teachers, European Physical Education Review, 3 (2), 116--128.

Hayes, S., Capel, S., Katene, W. and Velija, P. (2007) An examination of knowledge prioritisation in secondary physical education teacher education courses, manuscript accepted for publication in Teaching and Teacher Education.

Hoyle, E. and John, P. (1995) Professional knowledge and professional practice (London, Cassell).

Kirk, D. and Kinchin, G. (2003) Situated learning as a theoretical framework for sport education, European Physical Education Review, 9 (3), 221--236.

Kirk, D. and Macdonald, D. (1998) Situated learning in physical education, Journal of Teaching in Physical Education, 17, 376--387. 
Lawrence, J., Ashford, K. and Dent, P. (2006) Gender differences in coping strategies of undergraduate students and their impact on self-esteem and attainment, Active Learning in Higher Education, 7 (3), 273--281.

Lawson, H. A. (1983a) Toward a model of teacher socialization in physical education: the subjective warrant, recruitment, and teacher education (part 1), Journal of Teaching in Physical Education, 2 (3), 3--16.

Lawson, H. A. (1983b) Toward a model of teacher socialization in physical education: entry into schools, teachers' role orientations, and longevity in teaching (part 2), Journal of Teaching in Physical Education, 3 (1), 3--15.

Lawson, H.A. (1986) Occupational socialization and the design of teacher education programs, Journal of Teaching Physical Education, 5 (1), 107--116.

Lortie, D.C. (1975) School teacher: a sociological study (Chicago, Ill, University of Chicago Press).

Marton, F. and Saljo, R. (1997) Approaches to learning, in: F. Marton, D. Hounsell and N. Entwistle (Eds) The experience of learning: implications for teaching and studying in higher education, 2nd edn (Edinburgh, Scottish Academic Press), 39--58.

Marton, F., Dall'Alba, G. and Beaty, E. (1993) Conceptions of learning, International Journals of Educational Research, 19 (3), 277--300.

Mawer, M. (1996) Mentoring in physical education: issues and insights (London, Longman).

Mawer, M. (1999) Teaching styles and teaching approaches in physical education: research developments, in: C. Hardy and M. Mawer (Eds) Learning and teaching in physical education (London, Falmer Press).

Maynard, T. and Furlong, G.J. (1993) Learning to teach and models of mentoring, in: D. McIntryre, H. Hagger, and M. Wilkin (Eds) Mentoring: perspectives on school-based teacher education (London, Kogan Page), 69--85.

Meek, G. (1996) The teacher concerns questionnaire with pre-service physical educators in Great Britain: being concerned with concerns, Journal of Teaching in Physical Education, 16, 20--29.

Metzler, M. (Ed.) (2000) The physical education teacher education assessment project, Journal of Teaching in Physical Education (Special edition), 19 (4).

Munby, H., Russell, T. and Martin, A.K. (2001) Teachers' knowledge and how it develops, in: V. Richardson (Ed.) Handbook of research on teaching (Washington, American Educational Research Association), 877--904.

Ofsted (Office for Standards in Education) (1995) Physical education and sport in schools: a survey of good practice (London, HMSO).

Ofsted (Office for Standards in Education) (2002) Secondary subject reports 2000/01: physical education (London, HMSO).

Penney, D. and Evans, J. (1994) It's just not (and not just) Cricket, The British Journal of Physical Education, 25, 9--12.

Penney, D. and Evans, J. (1997) Naming the game: discourse and domination in physical education and sport in England and Wales, European Physical Education Review, 3 (1), $21--32$.

Penney, D. and Evans, J. (1999) Politics, policy and practice in physical education (London, FN Spon/Routledge).

Penney, D. and Evans, J. (2005) Policy, power and politics in physical education, in: K. Green and K. Hardman (Eds) Physical education essential issues (London, Sage).

Placek, J.H., Dodds, P., Doolittle, S.A., Portman, P.A., Ratliffe, T.A. and Pinkham, K.M. (1995) Teaching recruits' physical education backgrounds and beliefs about purposes for their subject mater, Journal of Teaching in Physical Education, 14, 246--261. 
Rossi, T. and Cassidy, T. (1999) Knowledgeable teachers in physical education: a view of teachers' knowledge, in: C.A. Hardy and M. Mawer (Eds) Learning and teaching in physical education (London, Falmer Press).

Schempp, P. (1989) Apprenticeship of observation and the development of physical education teachers, in: T.J. Templin and P. Schempp (Eds) Socialization into physical education: learning to teach (Indianapolis, IN, Benchmark Press), 13--38.

Shulman, L.S. (1986) Those who understand: knowledge growth in teaching, Educational Researcher, 57, 4--14.

Shulman, L.S. (1987) Knowledge and teaching: foundations of a new reform, Harvard Educational Review, 57, 1--22.

Solmon, M.A. and Ashy, M.H. (1995) Value orientations of preservice teachers, Research Quarterly for Exercise and Sport, 66, 219--230.

Stidder, G. and Hayes, S. (2006) A longitudinal study of physical education teachers' experiences on school placements in the south-east of England (1994-2004), European Physical Education Review, 12 (2), 313--333.

Stroot, S.A. and Ko, B. (2006) Induction of beginning physical educators into the school setting, in: D. Kirk, D. Macdonald and M. O'Sullivan (Eds) The handbook of physical education (London, Sage) 425--448.

Teachernet (2007) http://www.teachernet.gov.uk/teachingandlearning/subjects/pe/nationalstrategy/. Accessed 6 September, 2007.

Templin, T.J. (1979) Occupational socialization and the physical education student teacher, Research Quarterly for Exercise and Sport, 50, 482--493.

Thomson, P. (1999) How doing justice got boxed in: a cautionary curriculum tale for policy analysts, in: B. Johnson and A. Reid (Eds) Contesting the curriculum (Katoomba, NSW, Social Sciences Press), 24--42.

Tinning, R. (2006) Theoretical orientations in physical education teacher education, in: D. Kirk, D. Macdonald and M. O'Sullivan (Eds) The handbook of physical education (London, Sage), 369--385.

Tsangaridou, N. (2006) Teachers' beliefs, in: D. Kirk, D. Macdonald and M. O'Sullivan (Eds) The handbook of physical education (London, Sage), 486--501.

Vermunt, J. (1996) Metacognitive, cognitive, and affective aspects of learning styles and strategies: A phenomenonographic analysis, Higher Education, 31, 25--50.

Wendt, J. and Bain, L. (1989) Concerns of pre-service and in-service physical educators, Journal of Teaching in Physical Education, 8, 177--180.

Williams, A. (1993) The reflective physical education teacher: Implications for initial teacher education, Physical Education Review, 16 (2), 137--144. 